\title{
Dome-shaped macula in oculocutaneous albinism
}

\author{
Vinod Kumar, Kabiruddin Molla, Parijat Chandra, Atul Kumar
}

Dr Rajendra Prasad Centre for Ophthalmic Sciences, All India Institute of Medical Sciences, Delhi, India

\section{Correspondence to} Dr Vinod Kumar, drvinod_agg@yahoo.com

Accepted 11 April 2016
CrossMark

To cite: Kumar V, Molla $\mathrm{K}$, Chandra $\mathrm{P}$, et al. BMJ Case Rep Published online:

[please include Day Month Year] doi:10.1136/bcr-2016215368

\section{DESCRIPTION}

A 13-year-old girl with oculocutaneous albinism presented with decreased vision and pendular nystagmus in both eyes since birth. The bestcorrected-visual-acuity in both eyes was 20/400 with $-2.0 \mathrm{D}$ sphere. Anterior segment examination of both eyes was unremarkable apart from light coloured irides. Ocular globes and motility were normal. Axial length was 23.56 and $23.52 \mathrm{~mm}$ in the right and left eye, respectively. Fundus of the right eye revealed lack of pigment in retinal pigment epithelium with visible large choroidal vessels (figure 1A). Swept-source optical coherence tomography (SSOCT, Topcon Inc) revealed a dome-shaped macula due to fusiform thickening of the sclera along with absence of the foveal contour, suggestive of foveal aplasia (figure 1B). Similar findings were seen in the left eye (figure $1 \mathrm{C}, \mathrm{D}$ ). The patient was instructed to use tinted glasses. The clinical picture remained unchanged at 3 months.

Dome-shaped macula was first described by Gaucher et al, ${ }^{1}$ in 2008 , as an inward, bulging protrusion of the macula inside the chorioretinal posterior concavity in highly myopic eyes. Later, Keane et $a l^{2}$ reported the present of a dome-shaped macula in a mild myopic anisometropia and speculated the role of ocular compensatory mechanism in the development of a dome-shaped macula. To our knowledge this is the first case report of a dome-shaped macula in association with oculocutaneous albinism. This case also highlights the utility of swept-source optical coherence tomography for obtaining good quality images in the presence of nystagmus, which may be attributed to its higher scanning speed as compared to that of spectral domain optical coherence tomography.

\section{Learning points}

Optical coherence tomography is the only method to detect dome-shaped macula, which, in our case report, was associated with oculocutaneous albinism.

- Higher scan speed (100 000/s) enables swept-source optical coherence tomography to easily image eyes with nystagmus in conditions such as oculocutaneous albinism.

\section{Competing interests None declared.}

Patient consent Obtained.

Provenance and peer review Not commissioned; externally peer reviewed.

\section{REFERENCES}

1 Gaucher D, Erginay A, Lecleire-Collet A, et al. Dome-shaped macula in eyes with myopic posterior staphyloma. Am J Ophthalmol 2008;145:909-14.

2 Keane PA, Mitra A, Khan IJ, et al. Dome-shaped macula: a compensatory mechanism in myopic anisometropia? Ophthalmic Surg Lasers Imaging 2012;43 Online:e52-4.
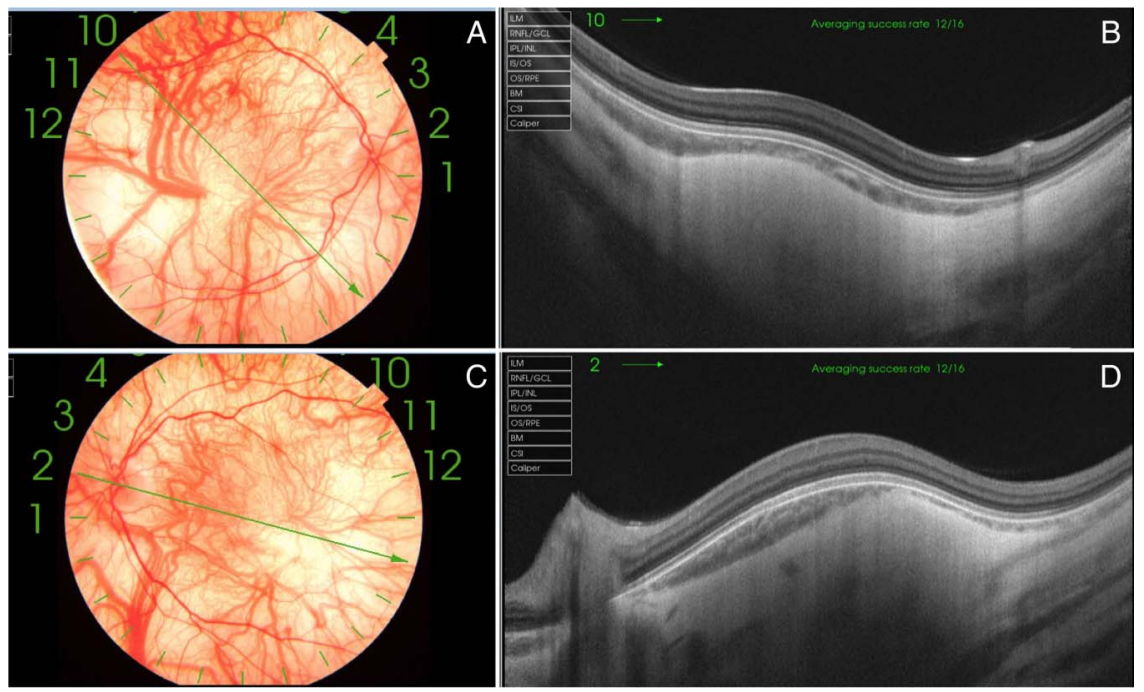

Figure 1 Colour fundus photograph of the right $(A)$ and left eye $(C)$ showing lack of pigment in retinal pigment epithelium and visible large choroidal vessels. Swept-source OCT of the right (B) and left eye (D), showing thickened sclera leading to a dome-shaped macula and absence of foveal contour. 


\section{Images in...}

Copyright 2016 BMJ Publishing Group. All rights reserved. For permission to reuse any of this content visit http://group.bmj.com/group/rights-licensing/permissions.

BMJ Case Report Fellows may re-use this article for personal use and teaching without any further permission.

Become a Fellow of BMJ Case Reports today and you can:

- Submit as many cases as you like

- Enjoy fast sympathetic peer review and rapid publication of accepted articles

- Access all the published articles

- Re-use any of the published material for personal use and teaching without further permission

For information on Institutional Fellowships contact consortiasales@bmjgroup.com

Visit casereports.bmj.com for more articles like this and to become a Fellow 